\title{
Pseudoainhum numa Doente com Doença Mista do Tecido Conjuntivo: Uma Associação Incomum
}

\author{
Sara Campos ${ }^{1}$, Ana Brasileiro², Joana Cabete 2 , Sofia Pinheiro ${ }^{3}$, André Lencastre², Maria João Paiva Lopes² \\ 'Resident of Dermatovenereology, Dermatovenereology Department, Hospital Santo António dos Capuchos - Centro Hospitalar \\ Lisboa Central, Lisbon, Portugal \\ ${ }^{2}$ Consultant of Dermatovenereology, Dermatovenereology Department, Hospital Santo António dos Capuchos - Centro Hospitalar \\ Lisboa Central, Lisbon, Portugal \\ ${ }^{3}$ Consultant of Internal Medicine, Internal Medicine Department, Hospital Santo António dos Capuchos - Centro Hospitalar Lisboa \\ Central, Lisbon, Portugal
}

RESUMO - Peudoainhum representa a formação de anéis constritivos em redor de um ou vários dedos. Pode ser congénito ou adquirido e, neste caso, pode estar associado a várias dermatoses como esclerose sistémica, queratodermias, psoríase, síndrome de Reynolds, entre outras. É apresentado o caso de uma mulher de 54 anos que foi referenciada por lesões digitais anulares constritivas e microníquia no quarto e quinto dedos das mãos associadas a acroesclerose distal bilateral. Salientava-se ainda a presença de fenómeno de Raynaud há vários anos e, mais recentes, fadiga e poliartralgias recorrentes de carácter inflamatório e ainda de anticorpos antinucleares e anticorpo anti-U1 ribonucleoproteína. Desta forma, foi considerado o diagnóstico de pseudoainhum associado a uma provável doença mista do tecido conjuntivo. É sabido que perante um caso de pseudoainhum, uma investigação etiológica aturada deve ser levada a cabo incluindo o despiste de doenças autoimunes. A associação de pseudoainhum com a doença mista do tecido conjuntivo não está descrita na literatura, razão pela qual este caso é apresentado. PALAVRAS-CHAVE - Ainhum/complicações; Constrição Patológica; Doença Mista do Tecido Conjuntivo.

\section{Pseudoainhum in a Patient with Mixed Connective Tissue Disease: An Uncommon Association}

ABSTRACT - The term pseudoainhum is used to describe constricting band(s) around one or more digits in relation to several congenital or acquired diseases. Systemic sclerosis, keratoderma, psoriasis, Reynolds syndrome among others, has been reported to be associated with pseudoainhum development. We report a case of a 54 years old woman with annular constricting bands and micronychia on the fourth and fifth digits of her both hands associated with bilateral distal acrosclerosis. Raynaud's phenomenon with some years of evolution and, more recent, fatigue and recurrent inflammatory polyarthritis and also antinuclear and anti- $U 1$ nuclear ribonucleoprotein antibodies were present. Therefore, the diagnoses of pseudoainhum with a likely association with mixed connective tissue disease were proposed. Whenever in the presence of pseudoainhum, a detailed workup, including autoimmune disorders screening, is mandatory in order to rule out possible associated syndromes or underlying diseases. The authors present this case as the association between pseudoainhum and mixed connective tissue disease has not been previously reported in the literature. KEYWORDS - Ainhum/complications; Constriction, Pathologic; Mixed Connective Tissue Disease.

Apresentações prévias do trabalho: Comunicação oral: "Doença mista do tecido conjuntivo com pseudo-ainhum associado", Reunião da Primavera da SPDV, 9-10 Maio 2014, Braga;

Poster: "Pseudoainhum in a patient with Mixed Connective Tissue Disease: an association not yet described", 24 nd EADV Congress, 7-11 Outubro 2015, Copenhaga.

Correspondência: Sara Leite de Azevedo Campos Dermatovenereology Department

Hospital Santo António dos Capuchos, Centro Hospitalar Lisboa Central

1169-050 Lisboa, Portugal

Tel.: + 351963542650

E-mail: saraazevedocampos@gmail.com
Recebido/Received

5 Outubro/October 2016

Aceite/Accepted

14 Dezembro/December 2016 


\section{Caso Clínico}

\section{INTRODUCTION}

Pseudoainhum is defined as the process of developing constrictive bands around digits that may ultimately lead to their autoamputation. As opposed to ainhum (dactylolysis spontanea), an idiopathic band-like constriction that affects toes of patients in the underdeveloped Third World, pseudoainhum is the secondary form and may be associated with hereditary and nonhereditary disorders, connective tissue diseases (CTDs) and keratinization syndromes (KS). ${ }^{1-3}$

We present a case of the previously unreported association, between pseudoainhum and mixed connective tissue disease (MCTD).

\section{CLINICAL CASE}

A 54-year-old woman of Indian ancestry was referred to our department with circumferential constricting bands on the $4^{\text {th }}$ and $5^{\text {th }}$ digits of her hands. She reported distal swelling and severe pain that had worsened in the previous 7 days. She also described long-standing dyspepsia, fatigue, recurrent inflammatory polyarthritis symptoms, and history of ovarian cancer one year ago treated with surgery and chemotherapy. Physical examination revealed that distal acrosclerotic changes were bilaterally present from the $2^{\text {nd }}$ to $5^{\text {th }}$ fingers, yet more severe on the $4^{\text {th }}$ and $5^{\text {th }}$, predominantly on the left, where micronychia was observable (Figs. 1 and 2). Slight edema of the entire left thumb was observable, which was nevertheless more noticeable on the fifth finger's proximal phalanx. Additionally, a variable degree of wrist and proximal

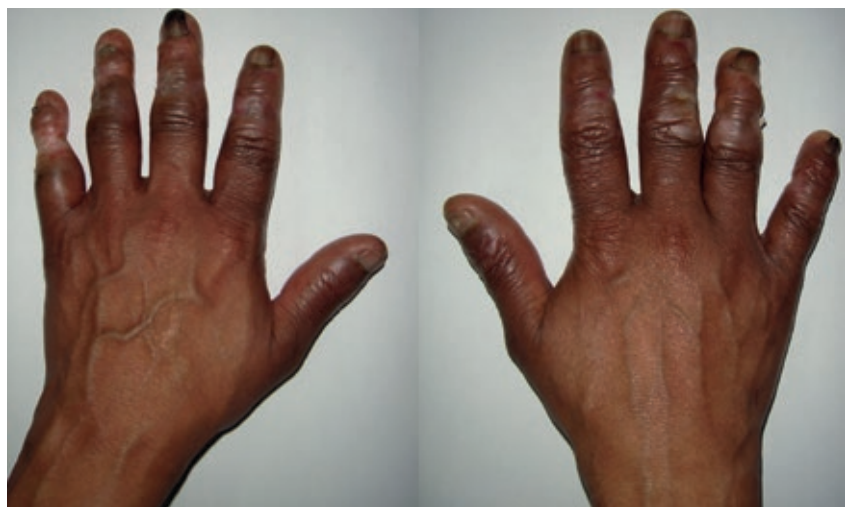

Figure 1 - Bilateral distal acrosclerotic changes were present on the $2^{\text {nd }}$ to $5^{\text {th }}$ fingers. Different degrees of pseudoainhum can be appreciated in each. However, it was worse on the $4^{\text {th }}$ right finger, and especially the 4th and 5th left fingers.

interphalangeal joints swelling was apparent, in a rheumatoid arthritis-like pattern. Raynaud's phenomenon (RP) was present, upon testing, and the patient disclosed a lasting account of bouts of similar symptoms. An autoimmune panel revealed positive anti-nuclear antibodies $(1 / 320$, speckled) and anti-U1 nuclear ribonucleoprotein (U1-RNP) antibodies (immunoblot), with normal titers of all other autoantibodies. Radiography of the hands revealed acral osteolysis on the $4^{\text {th }}$ and $5^{\text {th }}$ digits.

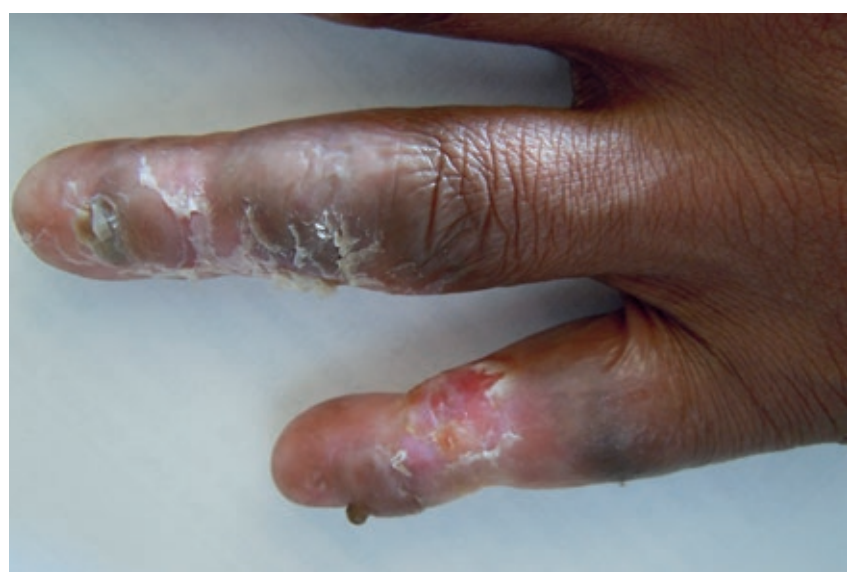

Figure 2 - Detail of the $4^{\text {th }}$ and $5^{\text {th }}$ left fingers. Acrosclerosis and onycoatrophy with micronychia.

Endoscopy, echocardiography, electrocardiogram, chest radiography and pulmonary function testing revealed no pathological findings. She denied neurologic complains, trauma or occupational cold exposure. Consequently, the diagnoses of MCTD and pseudoainhum were established.

The patient was treated transiently with azathioprine (150 mg id), pentoxifylline (400 mg tid), amlodipine (10 mg id), acetylsalicylic acid (150 mg id) and bosentan (125 mg bid). Due to multiple drug gastro-intestinal intolerance, IV ilosprost therapy was added, mainly with clinical improvement of pain and stabilization of the acrosclerosis. No auto-amputation occurred on a 3-year follow-up period, however her ovarian cancer eventually progressed and, at the end of this period, the patient died from metastatic disease.

\section{DISCUSSION}

Ainhum, a rare disorder of unknown cause and of mainly black patients, is characterized by the annular constriction and auto-amputation of the digits. Pseudoainhum, on the other hand, occurs as a result of an identifiable disease in patients of all ethnicities. ${ }^{1,3}$ A detailed workup to rule out associated syndromes or underlying diseases should therefore be performed, considering the possibility of scleroderma, discoid lupus erythematous, KS (Vohwinkel's syndrome and Mal de Meleda), psoriasis and Reynolds syndrome. ${ }^{1,2,4,5}$

Due to this patient's positivity to anti-U1-RNP antibodies we considered a possible MCTD. She met sufficient criteria (namely RP, anti-U1-RNP positivity, polyarthritis and sclerodactily) as defined by Kasukawa et al (neither Sharp, Kahn or Alarcón-Segovia classifications were applicable, because an anti-RNP titer was not available). ${ }^{6}$ We admit that her clinical picture resembled localized systemic sclerosis (SSc) to a certain degree. Yet, despite having RP, her specific sclerodactily pattern was not quite as described for the ACR/EULAR SSc classification criteria. ${ }^{7}$

Ultimately, in our patient, the pseudoainhum motivated referral and disclosed the underlying MCTD. It is conceivable that vascular anomalies observed in RP and SSc, drive the acrosclerotic changes in the same way that they eventually 


\section{Caso Clínico}

cause pseudoainhum, in some patients, as previously noted. ${ }^{8}$ The same is inferable in our case, as sclerosis was significantly worse in the 2 afflicted fingers compared to the others.

Due to its rarity, there are no well-established treatment recommendations for pseudoainhum. However, pseudoainhum is reportedly not an irreversible event, and it is possible to stop its progression.' Systemic retinoids have been used with benefit in patients with $\mathrm{KS}$, but recurrence on discontinuation is a problem. 5,9,10 More invasive approaches, including surgery, are associated with frequent recurrence. ${ }^{1,2}$ Tajima et al described a case of limited scleroderma with pseudoainhum successfully treated with tranilast, an anti-fibrotic agent. ${ }^{11}$ In our patient, treatment directed at her underlying disease also led to symptomatic improvement and stabilization of the pseudoainhum. In light of current literature, and because pseudoainhum may complicate underlying disease, treatment of the latter may be sufficient to prevent its progression. Further study is needed to find optimal treatment, nonetheless.

Our case suggests that MCTD may be considered when investigating acquired constricting bands of the digits.

Conflitos de interesse: Os autores declaram não possuir conflitos de interesse.

Suporte financeiro: $O$ presente trabalho não foi suportado por nenhum subsídio ou bolsa.

Confidencialidade dos dados: Os autores declaram ter seguido os protocolos do seu centro de trabalho acerca da publicação dos dados de doentes.

Protecção de pessoas e animais: Os autores declaram que os procedimentos seguidos estavam de acordo com os regulamentos estabelecidos pelos responsáveis da Comissão de Investigação Clínica e Ética e de acordo com a Declaração de Helsínquia da Associação Médica Mundial

Conflicts of interest: The authors have no conflicts of interest to declare.

Financing Support: This work has not received any contribution, grant or scholarship.

Confidentiality of data: The authors declare that they have followed the protocols of their work center on the publication of data from patients.

Protection of human and animal subjects: The authors declare that the procedures followed were in accordance with the regulations of the relevant clinical research ethics committee and with those of the Code of Ethics of the World Medical Association (Declaration of Helsinki).

\section{REFERENCES}

1. Rashid RM, Cowan E, Abbasi SA, Brieva J, Alam M. Destructive deformation of the digits with auto-amputation: a review of pseudo-ainhum. J Eur Acad Dermatol Venereol. 2007; $21: 732-7$.

2. Wollina U, Graefe T, Oelzner P, Hein G, Schreiber G. Pseudoainhum of all fingers associated with Reynolds' syndrome and breast cancer: report of a case and review of the literature. J Am Acad Dermatol. 2001; 44 (2 Suppl.):381-4.

3. Prabhu R, Kannan NS, Vinoth S, Praveen CB. Ainhum a rare case report. J Clin Diagn Res. 2016; 10:17-8.

4. Sharma RC, Sharma AK, Sharma NL. Pseudo-ainhum in discoid lupus erythematosus. J Dermatol. 1998; 25:275-6.

5. Almond SL, Curley RK, Feldberg L. Pseudoainhum in chronic psoriasis. Br J Dermatol. 2003; 149:1064-6.

6. Farhey Y, Hess EV. Review: mixed connective tissue disease. Arthritis Care Res. 1997; 10: 333-42.

7. van den Hoogen F, Khanna D, Fransen J, Johnson SR, Baron M, Tyndall A. 2013 classification criteria for systemic sclerosis: an American College of Rheumatology/ European League against Rheumatism collaborative initiative. Arthritis Rheum. 2013; 65:2737-47.

8. Park BS, Cho KH, Youn Jl, Chung JH. Pseudoainhum associated with linear scleroderma. Arch Dermatol. 1996; 132:1520-1.

9. Chang Sing Pang A, Oranje A, Vuzevki V, Stolz E. Successful treatment of keratoderma hereditaria mutilans with an aromatic retinoid. Arch Dermatol. 1981; 117:225-8.

10. Camisa C, Rossana C. Variant of keratoderma hereditaria mutilans (Vohwinkel's syndrome). Arch Dermatol. 1984; 120:1323-8.

11. Tajima S, Suzuki Y, Inazumi T. A case of atypical localized scleroderma presenting with pseudoainhum: treatment with tranilas.t, an anti-fibrotic agent. Acta Derm Venereol. 1996; 76:162. 